\title{
THE IMPACT OF HUMAN CAPITAL DEVELOPMENT ON COMPETITIVENESS
}

\author{
Tamara Rađenović, \\ Bojan Krstic
}

University of Niš, Faculty of Economics, Niš, Serbia

\begin{abstract}
:
Intellectual resources are the main drivers of competitiveness in the knowledge economy. The literature dealing with intellectual capital mainly distinguishes three components of intellectual capital - human, structural and relational capital. The component that has the most significant influence on value creation and competitiveness is human capital. Thus, the aim of this paper is to determine the impact of human intellectual capital on competitiveness in the EU countries and Serbia, as well as to examine to what extent Serbia lags behind the EU countries regarding human capital development. The obtained results show that human capital has significant impact on competitiveness in the EU countries and Serbia, and that Serbia considerably lags behind the EU countries as regards human capital development.
\end{abstract}

Keywords:

intellectual capital, human capital, competitiveness.
Correspondence:

Tamara Rađenović

e-mail:

tamara.radjenovic@eknfak.ni.ac.rs

\section{INTRODUCTION}

In the contemporary society, economic and social changes, induced by the development of science and technology, have been reflected in the relative importance of the economic resources - physical, financial, human and other intellectual resources. This shift, from tangible to intangible resources in the process of value creation, was especially emphasized in the early $21^{\text {st }}$ century. Technological advances have paved the way for the increased usage of immaterial resources, especially knowledge, in the production process. Once the knowledge has become the main source of economic growth and development, the industrial economy has been replaced by the knowledge economy. ${ }^{1}$ Hence, knowledge, innovations and networking have become the fundamental elements of the infrastructure needed for the prosperity in the new knowledge economy. ${ }^{2}$

Opposite to tangible resources, characterized by the diminishing returns, the intellectual resources are characterized by the increasing returns, and thus, are the constant source of competitiveness, efficiency of enterprises and prosperity of national economies. Intellectual capital represents knowledge that can be turned into profit. ${ }^{3}$ Although according to researchers there are various components of intellectual capital (e.g. human capital, structural capital, relational capital, innovation capital, social capital, renewal

1 Krstić, B., \& Stanišić, T. (2013). The Influence of Knowledge Economy Development on Competitiveness of Southeastern Europe Countries. Industrija, 141(2), 151-168. doi:10.5937/industrija41-4000

2 Krstić, B., \& Vukadinović, D. (2009). Valorizovanje resursa znanja - metodologija nacionalnog indeksa intelektualnog kapitala. U Z. Arandjelović, Regionalni razvoj i demografski tokovi zemalja jugoistočne Evrope (str. 459-468). Niš: Univerzitet u Nišu, Ekonomski fakultet.

3 Sullivan, P. (2000). Value-Driven Intellectual Capital - How to Convert Intangible Corporate Assets into Market Value. New York: John Wiley. 
capital, entrepreneurship capital, trust capital, etc.), ${ }^{4}$ it generally consists of human, structural and relational capital. The examinations and analyses of intellectual capital at microeconomic and macroeconomic levels, have raised extensive researches regarding its measurement issues, and especially investigations of its impact on the performances of the enterprises, regions and national economies. The most important component of intellectual capital is human capital, since it represents a base for creation of the other two components of intellectual capital at the organizational level. Also, progression from resource-based economies to knowledge-based economies puts human capital in the center of public policy themes. $^{5}$

Therefore, the aim of this paper is to determine the impact of human capital development on competitiveness, but also the extent to which Serbia lags behind the EU countries regarding human capital development. The paper is structured as follows: following the introduction, the review of literature dealing with human capital and competitiveness is presented, followed by the data and methodology issues. The subsequent section deals with the analysis of the obtained results and at the end the conclusion summarizesthe main findings.

\section{LITERATURE REVIEW}

The expansion of scientific knowledge, which increases the productivity of labor and other production inputs, has been partly attributable to the continuing economic growth and development in many countries during $19^{\text {th }}$ and $20^{\text {th }}$ centuries, thus leading to the increased importance of education, technical schooling, on-the-job training and other human capital. ${ }^{6}$ Human capital includes qualifications, skills, work habits, professional experience, training, motivation, loyalty, learning and increasing capabilities of employees and other performances. ${ }^{7}$ Human capital also involves collective (organizational) experience, organizational memory and know-how of the employees in an organization. ${ }^{8}$ But, apart from professional competencies, for the firm to succeed,

4 Inkinen, H. (2015). Review of empirical research on intellectual capital and firm performance. Journal of Intellectual Capital, 16(3), 518-565. doi:10.1108/JIC-01-2015-0002; Inkinen, H., Kianto, A., Vanhala, M., \& Ritala, P. (2017). Structure of intellectual capital an international comparison. Accounting, Auditing \& Accountability Journal, 30(5), 1160-1183. doi:10.1108/AAAJ-11-2015-2291.

5 Laroche, M., Mérette, M., \& Ruggeri, G. C. (1999). On the Concept and Dimensions of Human Capital in a Knowledge-Based Economy Context. Canadian Public Policy - Analyse de Politiques, 25(1), 87-100.

6 Becker, G. S. (2008). "Human Capital", The Concise Encyclopedia of Economics. Library of Economics and Liberty. Retrieved April 18, 2017, from http://www.econlib.org/library/Enc/HumanCapital.html

7 Krstić, B. (2014). Upravljanje intelektualnim kapitalom preduzeća. Niš: Ekonomski fakultet Univerziteta u Nišu.

8 Sullivan, P. H. (1998). Basic Definitions and Concepts. In P. H. Sullivan, Profiting from Intellectual Capital: Extracting Value from Innovation (pp. 19-34). New York: John Wiley \& Sons, Inc.

9 Jelčić, K. (2007). Intellectual Capital: Handbook of IC Management in Companies. Zagreb: Intellectual Capital Center Croatia. employees must possess social, commercial andemotional competences as well..$^{9}$ Although knowledge and competences are important aspects of human capital quality, the extent to which an organization is able to use them depends on the health of employees. This is mainly due to the fact that physi$\mathrm{cal}$ and mental health have a crucial role in the readiness of an individual to achieve high efficiency, flexibility and innovativeness and his/her reaction to the highly competitive and stressful work environment. ${ }^{10}$ Thus, to efficiently use and improve its human capital, every organization and nation should focus on continuous and systematic management of this valuable resource.

The importance of human capital for the success of an organization and the national economy has been well recognized in theory. The foundations of human capital theory can be traced back to the 1776 and capital work of Adam Smith, while the theoretical and empirical grounds of modern human capital theory were established by the late 1960s with the work of Mincer, Schultz and Becker. ${ }^{11}$ The human capital theorists consider human capital as an independent category which possesses the same economic and production characteristics as conventional capital, ${ }^{12}$ and hence, it is the most valuable production resource which leads to the improved efficiency and economic prosperity. While, the neoclassical growth theory, recognized knowledge and human capital as exogenous, the new growth theory extends the basis Solow's model by incorporating different types of labor (e.g. different years of schooling, qualifications, occupations, etc.), i.e. accumulation of human capital, as an additional independent variable in the model. ${ }^{13}$

Based on the endogenous growth models, numerous researches have been conducted covering a wide range of countries with the aim of determining the impact of human capital on the economic growth and competitiveness. In these studies, the education expenditures are considered investments for the development of individuals instead of costs. The study conducted by Barro ${ }^{14}$ covering the sample

10 Ahonen, G., Hussi, T., \& Schunder-Tatzber, S. (2007). Work-Related Well-Being: A Precondition for Intellectual Capital. In C. Chaminade, \& B. Catasús, Intellectual Capital Revisited: Paradoxes in the Knowledge Intensive Organization (pp. 31-44). Cheltenham, UK: Edward Elgar.

11 Sweetland, S. R. (1996). Human Capital Theory: Foundations of a Field of Inquiry. Review of Educational Research, 66(3), 341-359. Nerdrum, L., \& Erikson, T. (2001). Intellectual Capital: A Human Capital Perspective. Journal of Intellectual Capital, 2(2), 127-135. doi:10.1108/14691930110385919

12 Nerdrum, L., \& Erikson, T. (2001). Intellectual Capital: A Human Capital Perspective. Journal of Intellectual Capital, 2(2), 127-135. doi:10.1108/14691930110385919

13 Mankiw, G. N., Romer, D., \& Weil, D. N. (1992). A Contribution to the Empirics of Economic Growth. The Quarterly Journal of Economics, 407-437. Wilson, R. A., \& Briscoe, G. (2004). The Impact of Human Capital on Economic Growth: A Review. In P. Descy, \& M. Tessaring (Eds.), Impact of Education and Training (Third report on vocational training research in Europe: background report) (pp. 9-70). Cedefop Reference series, 54. Luxembourg: Office for Official Publications of the European Communities.

14 Barro, R. J. (1999). Human Capital and Growth in Cross-Country Regressions. Swedish Economic Policy Review, 6(2), 237-277. 
of 100 countries during 1960-1995 confirmed that average years of adult-male schooling after primary level has positive impact on economic growth, and that quality of education, especially scores related to scientific performances, have significant role in explaining economic growth. These results are in line with the results of the study conducted by Bassanini and Scarpetta for the OECD countries covering period 1971-1998 and study conducted by Cohen and Soto on a sample of 95 countries during 1960-2000, which confirmed that the average years of schooling have a positive impact on the economic growth. ${ }^{15}$

Research conducted by Baldacci et al..$^{16}$ on the sample of 118 countries during 1975-2000 revealed positive impact of education, as well as, education expenditures on the economic growth. Their results determined significant time lag between an increase in the education expenditures and the manifestation of their effects on social indicators and economic growth, where $2 / 3$ of education expenditures materialized in a 5 year period, while a full effect was achieved with the time lag of 10-15 years. The importance of public expenditures on education for the economic growth was confirmed by Neycheva ${ }^{17}$ in $20 \mathrm{EU}$ countries for the period 1995-2009. However, the study by Pelinescu ${ }^{18}$ revealed the negative impact of education expenditures on GDP per capita for the period 2002-2012.

Study by Suri et al. ${ }^{19}$ revealed that the level of human development is important for determining growth paths, and hence policies that improve human development must precede or at least complement growth policies. Another study by Sverdlova ${ }^{20}$ discovered the dependence between human capital development and national competitiveness. These results are in line with the results obtained by Lonska and Mietule $^{21}$ that the increase of human capital leads to the improved competitiveness of a country.

Based on the abovementioned studies it is evident that human capital is an important determinant of economic growth and competitiveness. However, while the consensus among researchers exists when indicators for measuring economic growth and competitiveness are in question, the situation is quite different regarding human capital since researchers use various proxy indicators for measuring particular dimensions of human capital.

15 Bassanini, A., \& Scarpetta, S. (2001). Does Human Capital Matter for Growth in OECD Countries?: Evidence from Pooled MeanGroup Estimates. OECD Economics Department Working Papers, No. 282. Paris: OECD Publishing. doi:10.1787/4243002442762; Cohen, D., \& Soto, M. (2007). Growth and Human Capital: Good Data, Good Results. Journal of Economic Growth, 12(1), 51-76. doi:10.1007/s10887-007-9011-5.

16 Baldacci, E., Clements, B., Gupta, S., \& Cui, Q. (2008). Social Spending, Human Capital, and Growth in Developing Countries. World Development, 36(8), 1317-1341. doi:10.1016/j.worlddev.2007.08.003.

17 Neycheva, M. (2010). Does Public Expenditure on Education Matter for Growth in Europe? A Comparison Between Old EU Member States and Post-Communist Economies. Post-Communist Economies, 22(2), 141-164. doi:10.1080/14631371003740597.

18 Pelinescu, E. (2015). The Impact of Human Capital on Economic Growth. Procedia Economics and Finance, 22, 184-190. doi:10.1016 S2212-5671(15)00258-0.

\section{DATA AND METHODOLOGY}

Data used in this study are collected from relevant international databases - the UNDP of Human Development Index (HDI), and the World Economic Forum (WEF) of the Global Competitiveness Index (GCI).22 The sample includes $28 \mathrm{EU}$ countries and Serbia.

The aim of the paper is to determine the impact of human capital on competitiveness in the EU countries and Serbia. The following hypotheses are tested:

H1: Serbia lags behind the EU countries regarding human capital development;

H2: Human capital development has a significant impact on the competitiveness of the national economy.

In order to test these hypotheses, comparative, benchmarking, correlation and regression analyses are conducted. Comparative and benchmarking analyses are conducted for the verification of hypothesis $\mathrm{H} 1$, while correlation and regression analyses are conducted for the verification of hypothesis $\mathrm{H} 2$. The statistical package SPSS 15.0 is used for the data analyses.

\section{RESULTS AND DISCUSSION}

UNDP starting from 1990 has calculated and reported data on HDI, which integrates the three basic dimensions of human development: life expectancy at birth (reflecting the ability to live a long and healthy life), mean years of schooling and expected years of schooling (reflecting the ability to acquire knowledge), and gross national income per capita (reflecting the ability to achieve a decent standard of living). ${ }^{23}$ HDI takes values from 0 (the lowest level of human development) to 1 (the highest level of human development). Table 1 represents the value of HDI for the EU countries and Serbia covering the period from 1990-2015.

Based on these data it is evident that Serbia had the HDI values below the average level of the $\mathrm{EU}$ countries during the whole analyzed period. Also, Serbia significantly lagged behind the best performers in the EU. Netherlands was the best performer regarding HDI from 1990-2000, Denmark in 2005 and 2011-2013, and Germany in 2010 and 2014-2015.

19 Suri, T., Boozer, M. A., Ranis, G., \& Stewart, F. (2011). Paths to Success: The Relationship Between Human Development and Economic Growth. World Development, 39(4), 506-522. doi:10.1016/j. worlddev.2010.08.020.

20 Sverdlova, Y. (2014). Influence of Human Capital Development on Competitiveness of the EU Economy. Economic Annals-XXI, 7-8(2), $12-15$.

21 Lonska, J., \& Mietule, I. (2015). The impact of human capital development on the economic and social development of a country: empirical study. Proceedings of the $10^{\text {th }}$ International Scientific and Practical Conference "Environment. Technology. Resources". Volume II (pp. 174-180). Rezekne, Latvia: Rezekne Higher Education Institution. doi:10.17770/etr2015vol2.268.

22 http://hdr.undp.org/en/data; http://reports.weforum.org/globalcompetitiveness-index-2017-2018/downloads/

23 UNDP. (2016). Human Development Report 2016: Human Development for Everyone. New York: UNDP, p. 3. 
The development of human capital in these countries was well above the average of the EU countries. The lowest human capital development was reported in Croatia in 1990, Latvia in 1995, Romania in 2000, and Bulgaria during the remaining analyzed period from 2005-2015. During the period 1990-2000 Serbia reported HDI values above the worst performers in the EU, but from 2005-2015 Serbia had lower values of HDI than Bulgaria (Figure 1). These results indicate that human capital development in Serbia was below the development levels achieved in the EU countries, and for Serbia this should be an important policy area in the forthcoming period.

Table 1. Human Development Index in the EU countries and Serbia

\begin{tabular}{|c|c|c|c|c|c|c|c|c|c|c|}
\hline Country & 1990 & 1995 & 2000 & 2005 & 2010 & 2011 & 2012 & 2013 & 2014 & 2015 \\
\hline Austria & 0.794 & 0.816 & 0.837 & 0.854 & 0.880 & 0.884 & 0.887 & 0.892 & 0.892 & 0.893 \\
\hline Belgium & 0.805 & 0.851 & 0.873 & 0.865 & 0.884 & 0.886 & 0.889 & 0.890 & 0.895 & 0.896 \\
\hline Bulgaria & 0.700 & 0.702 & 0.713 & 0.750 & 0.775 & 0.778 & 0.781 & 0.787 & 0.792 & 0.794 \\
\hline Croatia & 0.669 & 0.695 & 0.749 & 0.783 & 0.808 & 0.815 & 0.817 & 0.820 & 0.823 & 0.827 \\
\hline Cyprus & 0.733 & 0.784 & 0.800 & 0.829 & 0.847 & 0.850 & 0.850 & 0.850 & 0.854 & 0.856 \\
\hline Czech Republic & 0.761 & 0.785 & 0.821 & 0.847 & 0.861 & 0.864 & 0.865 & 0.871 & 0.875 & 0.878 \\
\hline Denmark & 0.799 & 0.830 & 0.862 & 0.902 & 0.910 & 0.922 & 0.924 & 0.926 & 0.923 & 0.925 \\
\hline Estonia & 0.728 & 0.722 & 0.781 & 0.822 & 0.838 & 0.850 & 0.856 & 0.860 & 0.863 & 0.865 \\
\hline Finland & 0.783 & 0.815 & 0.856 & 0.869 & 0.878 & 0.884 & 0.887 & 0.890 & 0.893 & 0.895 \\
\hline France & 0.779 & 0.825 & 0.849 & 0.870 & 0.882 & 0.885 & 0.887 & 0.890 & 0.894 & 0.897 \\
\hline Germany & 0.801 & 0.834 & 0.860 & 0.892 & 0.912 & 0.916 & 0.919 & 0.920 & 0.924 & 0.926 \\
\hline Greece & 0.760 & 0.774 & 0.801 & 0.850 & 0.860 & 0.858 & 0.860 & 0.862 & 0.865 & 0.866 \\
\hline Hungary & 0.703 & 0.741 & 0.769 & 0.802 & 0.821 & 0.823 & 0.824 & 0.834 & 0.834 & 0.836 \\
\hline Ireland & 0.762 & 0.794 & 0.857 & 0.896 & 0.909 & 0.895 & 0.902 & 0.910 & 0.920 & 0.923 \\
\hline Italy & 0.768 & 0.799 & 0.828 & 0.856 & 0.872 & 0.877 & 0.876 & 0.877 & 0.881 & 0.887 \\
\hline Latvia & 0.703 & 0.674 & 0.728 & 0.807 & 0.810 & 0.812 & 0.814 & 0.822 & 0.828 & 0.830 \\
\hline Lithuania & 0.731 & 0.702 & 0.757 & 0.807 & 0.826 & 0.830 & 0.834 & 0.841 & 0.846 & 0.848 \\
\hline Luxembourg & 0.782 & 0.808 & 0.854 & 0.880 & 0.894 & 0.892 & 0.892 & 0.892 & 0.896 & 0.898 \\
\hline Malta & 0.736 & 0.758 & 0.783 & 0.809 & 0.826 & 0.821 & 0.828 & 0.847 & 0.853 & 0.856 \\
\hline Netherlands & 0.830 & 0.863 & 0.878 & 0.893 & 0.911 & 0.921 & 0.922 & 0.923 & 0.923 & 0.924 \\
\hline Poland & 0.712 & 0.738 & 0.784 & 0.803 & 0.829 & 0.834 & 0.838 & 0.850 & 0.852 & 0.855 \\
\hline Portugal & 0.711 & 0.759 & 0.782 & 0.793 & 0.818 & 0.824 & 0.827 & 0.837 & 0.841 & 0.843 \\
\hline Romania & 0.700 & 0.686 & 0.708 & 0.755 & 0.798 & 0.797 & 0.794 & 0.797 & 0.798 & 0.802 \\
\hline Slovakia & 0.738 & 0.750 & 0.763 & 0.793 & 0.829 & 0.835 & 0.838 & 0.841 & 0.842 & 0.845 \\
\hline Slovenia & 0.767 & 0.782 & 0.824 & 0.858 & 0.876 & 0.877 & 0.878 & 0.888 & 0.888 & 0.890 \\
\hline Spain & 0.755 & 0.801 & 0.825 & 0.844 & 0.867 & 0.871 & 0.874 & 0.877 & 0.882 & 0.884 \\
\hline Sweden & 0.815 & 0.856 & 0.877 & 0.892 & 0.901 & 0.903 & 0.904 & 0.906 & 0.909 & 0.913 \\
\hline United Kingdom & 0.775 & 0.839 & 0.866 & 0.890 & 0.902 & 0.898 & 0.899 & 0.904 & 0.908 & 0.910 \\
\hline EU average & 0.754 & 0.778 & 0.810 & 0.840 & 0.858 & 0.861 & 0.863 & 0.868 & 0.871 & 0.874 \\
\hline Serbia & 0.714 & 0.694 & 0.709 & 0.739 & 0.757 & 0.767 & 0.766 & 0.771 & 0.775 & 0.776 \\
\hline
\end{tabular}

Source: Authors' presentation based on the data from http://hdr.undp.org/en/data 
Figure 1. The comparison of HDI in the EU and Serbia

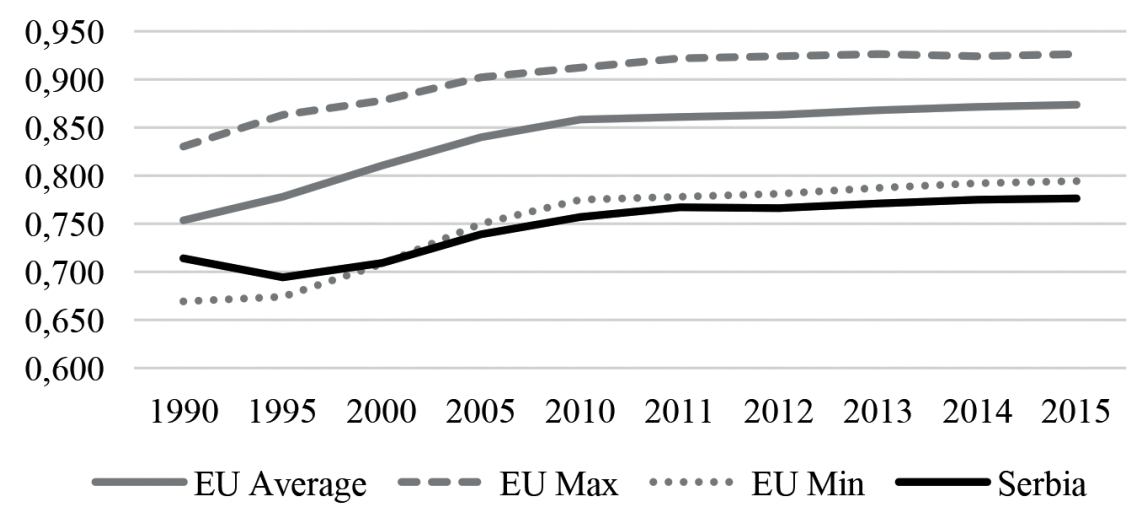

Every year for almost four decades, WEF has published the Global Competitiveness Report, which has kept track of the progress of various factors and institutions significant for economic development and competitiveness, and enabled benchmarking of countries regarding competitiveness. ${ }^{24}$ $\mathrm{GCI}$ is a composite index comprising twelve competitiveness pillars grouped within three subindexes: Basic requirements (Institutions, Infrastructure, Macroeconomic environment, Health and primary education), Efficiency enhancers (Higher education and training, Goods market efficiency, Labor market efficiency, Financial market development, Technological readiness, Market size), and Innovation and sophis- tication factors (Business sophistication, Innovation). ${ }^{25} \mathrm{GCI}$ takes values from 1 (the worst score) to 7 (the best score). Table 2 represents the value of GCI for the EU countries and Serbia covering the period from 2010-2015.

Based on the data from Table 2 and Figure 2 it is evident that Serbia lagged behind the EU most competitive countries, as well as, the average EU values during the analyzed period 2010-2015. Greece was the least competitive country in the EU during the analyzed period, while Sweden was the most competitive country in the EU during 2010-2011, Finland during 2012-2014, and Germany in 2015. Serbia had the values of GCI lower than Greece in all years, except 2012.

Figure 2. The comparison of GCI in the EU and Serbia

achieved in 2010 (0.841), while the weakest positive correlation was achieved in 2014 (0.802). The regression results presented in Table 4 show that changes in HDI values could significantly explain changes in GCI, in $2010-70.7 \%$, in 2011 $-70.5 \%$, in $2012-69.1 \%$, in $2013-66.4 \%$, in $2014-64.3 \%$, and in $2015-68.2 \%$. All regression models were statistically significant, and by increasing HDI by 1 unit, the GCI increased by around 10 units during the analyzed period.

25 WEF. (2016). The Global Competitiveness Report 2016-2017. (K. Schwab, Ed.) Geneva: WEF, p. 5. 
Table 2. Global Competitiveness Index in the EU countries and Serbia

\begin{tabular}{|c|c|c|c|c|c|c|}
\hline Country & 2010 & 2011 & 2012 & 2013 & 2014 & 2015 \\
\hline Austria & 5.09 & 5.14 & 5.22 & 5.15 & 5.16 & 5.12 \\
\hline Belgium & 5.07 & 5.20 & 5.21 & 5.13 & 5.18 & 5.20 \\
\hline Bulgaria & 4.13 & 4.16 & 4.27 & 4.31 & 4.37 & 4.32 \\
\hline Croatia & 4.04 & 4.08 & 4.04 & 4.13 & 4.13 & 4.07 \\
\hline Cyprus & 4.50 & 4.36 & 4.32 & 4.30 & 4.31 & 4.23 \\
\hline Czech Republic & 4.57 & 4.52 & 4.51 & 4.43 & 4.53 & 4.69 \\
\hline Denmark & 5.32 & 5.40 & 5.29 & 5.18 & 5.29 & 5.33 \\
\hline Estonia & 4.61 & 4.62 & 4.64 & 4.65 & 4.71 & 4.74 \\
\hline Finland & 5.37 & 5.47 & 5.55 & 5.54 & 5.50 & 5.45 \\
\hline France & 5.13 & 5.14 & 5.11 & 5.05 & 5.08 & 5.13 \\
\hline Germany & 5.39 & 5.41 & 5.48 & 5.51 & 5.49 & 5.53 \\
\hline Greece & 3.99 & 3.92 & 3.86 & 3.93 & 4.04 & 4.02 \\
\hline Hungary & 4.33 & 4.36 & 4.30 & 4.25 & 4.28 & 4.25 \\
\hline Ireland & 4.74 & 4.77 & 4.91 & 4.92 & 4.98 & 5.11 \\
\hline Italy & 4.37 & 4.43 & 4.46 & 4.41 & 4.42 & 4.46 \\
\hline Latvia & 4.14 & 4.24 & 4.35 & 4.40 & 4.50 & 4.45 \\
\hline Lithuania & 4.38 & 4.41 & 4.41 & 4.41 & 4.51 & 4.55 \\
\hline Luxembourg & 5.05 & 5.03 & 5.09 & 5.09 & 5.17 & 5.20 \\
\hline Malta & 4.34 & 4.33 & 4.41 & 4.50 & 4.45 & 4.39 \\
\hline Netherlands & 5.33 & 5.41 & 5.50 & 5.42 & 5.45 & 5.50 \\
\hline Poland & 4.51 & 4.46 & 4.46 & 4.46 & 4.48 & 4.49 \\
\hline Portugal & 4.38 & 4.40 & 4.40 & 4.40 & 4.54 & 4.52 \\
\hline Romania & 4.16 & 4.08 & 4.07 & 4.13 & 4.30 & 4.32 \\
\hline Slovakia & 4.25 & 4.19 & 4.14 & 4.10 & 4.15 & 4.22 \\
\hline Slovenia & 4.42 & 4.30 & 4.34 & 4.25 & 4.22 & 4.28 \\
\hline Spain & 4.49 & 4.54 & 4.60 & 4.57 & 4.55 & 4.59 \\
\hline Sweden & 5.56 & 5.61 & 5.53 & 5.48 & 5.41 & 5.43 \\
\hline United Kingdom & 5.25 & 5.39 & 5.45 & 5.37 & 5.41 & 5.43 \\
\hline EU average & 4.67 & 4.69 & 4.71 & 4.70 & 4.73 & 4.75 \\
\hline Serbia & 3.84 & 3.88 & 3.87 & 3.77 & 3.90 & 3.89 \\
\hline
\end{tabular}

Source: Authors' presentation based on the data from http://reports.weforum.org/global-competitiveness-index-2017-2018/downloads/ 
Table 3. The results of correlation analysis

\begin{tabular}{|c|c|c|c|c|c|c|}
\hline & $G C I_{10}$ & $G C I_{11}$ & $G C I_{12}$ & $G C I_{13}$ & $G C I_{14}$ & $G C I_{15}$ \\
\hline \multirow{2}{*}{$H D I_{10}$} & 0.841 & & & & & \\
\hline & {$[0.000]$} & & & & & \\
\hline \multirow{2}{*}{$H D R_{11}$} & & 0.840 & & & & \\
\hline & & {$[0.000]$} & & & & \\
\hline \multirow{2}{*}{$H D I_{12}$} & & & 0.831 & & & \\
\hline & & & {$[0.000]$} & & & \\
\hline \multirow{2}{*}{$H D I_{13}$} & & & & 0.815 & & \\
\hline & & & & {$[0.000]$} & & \\
\hline \multirow{2}{*}{$H D I_{14}$} & & & & & 0.802 & \\
\hline & & & & & {$[0.000]$} & \\
\hline \multirow{2}{*}{$H D I_{15}$} & & & & & & 0.826 \\
\hline & & & & & & {$[0.000]$} \\
\hline
\end{tabular}

Note: $p$ values in []

Source: Authors' calculation

Table 4 . The results of regression analysis

\begin{tabular}{|c|c|c|c|c|c|c|}
\hline Year & 2010 & 2011 & 2012 & 2013 & 2014 & 2015 \\
\hline \multirow{4}{*}{$\alpha$} & -3.680 & -4.384 & -4.442 & -4.309 & -3.832 & -4.356 \\
\hline & $(-3.563)$ & $(-3.886)$ & $(-3.778)$ & $(-3.506)$ & $(-3.125)$ & $(-3.646)$ \\
\hline & {$[0.001]$} & {$[0.001]$} & {$[0.001]$} & [0.002] & [0.004] & {$[0.001]$} \\
\hline & 9.744 & 10.551 & 10.613 & 10.377 & 9.840 & 10.430 \\
\hline \multirow{2}{*}{$\beta$} & $(8.072)$ & (8.029) & $(7.769)$ & (7.308) & $(6.971)$ & $(7.606)$ \\
\hline & {$[0.000]$} & {$[0.000]$} & {$[0.000]$} & {$[0.000]$} & {$[0.000]$} & {$[0.000]$} \\
\hline$R^{2}$ & 0.707 & 0.705 & 0.691 & 0.664 & 0.643 & 0.682 \\
\hline$\overline{R^{2}}$ & 0.696 & 0.694 & 0.679 & 0.652 & 0.630 & 0.670 \\
\hline \multirow{2}{*}{ F-statistics } & 65.151 & 64.470 & 60.356 & 53.406 & 48.590 & 57.852 \\
\hline & {$[0.000]$} & {$[0.000]$} & {$[0.000]$} & {$[0.000]$} & {$[0.000]$} & [0.000] \\
\hline
\end{tabular}

Note: dependent variable GCI in year $t=2010,2011, \ldots, 2015 ; \alpha$-regression constant; $\beta$ - regression coefficient of independent variable HDI in year $t$; $t$ statistics in ( ); $p$ values in [ ]

Source: Authors' calculation

\section{CONCLUSION}

The importance of human capital for economic growth and competitiveness has been well established in theory and practice. Many empirical studies reveal positive effect of human capital development on the economic growth and competitiveness across various countries. This paper contributes to the existing literature by empirical analysis of the relationship between human development and competitiveness in the EU countries and Serbia in the period 2010-2015.

Based on the conducted analysis authors determined that Serbia significantly lags behind the EU countries regarding human capital development, thus confirming the hypothesis H1. The situation is quite similar regarding competitiveness, since Serbia is less competitive country than the EU countries. The results also revealed that human capital development has positive effects on competitiveness in the analyzed countries, thus confirming hypothesis $\mathrm{H} 2$.

This trail behind the EU economies regarding human capital development and forming knowledge based economy puts emphasis on the policies aimed at the improvement of this area. Therefore, significant measures should be implemented regarding education and training of individuals, especially young ones, but also major actions should be focused 
on overcoming investment gaps in education and research and development in order to improve the Serbian competitiveness. These measures for improving human development should be accompanied by policies that create encouraging business environment for innovation and entrepreneurship, thus enabling Serbia to quickly reach the EU countries regarding human development and competitiveness.

\section{Acknowledgments:}

The paper is a result of research within project 179066 funded by the Ministry of Education, Science and Technological Development of the Republic of Serbia

\section{LITERATURE}

Ahonen, G., Hussi, T., \& Schunder-Tatzber, S. (2007). Work-Related Well-Being: A Precondition for Intellectual Capital. In C. Chaminade, \& B. Catasús, Intellectual Capital Revisited: Paradoxes in the Knowledge Intensive Organization (pp. 3144). Cheltenham, UK: Edward Elgar.

Baldacci, E., Clements, B., Gupta, S., \& Cui, Q. (2008). Social Spending, Human Capital, and Growth in Developing Countries. World Development, 36(8), 1317-1341. doi:10.1016 /j.worlddev.2007.08.003

Barro, R. J. (1999). Human Capital and Growth in Cross-Country Regressions. Swedish Economic Policy Review, 6(2), 237-277.

Bassanini, A., \& Scarpetta, S. (2001). Does Human Capital Matter for Growth in OECD Countries?: Evidence from Pooled Mean-Group Estimates. OECD Economics Department Working Papers, No. 282. Paris: OECD Publishing. doi:10. $1787 / 424300244276$

Becker, G. S. (2008). “Human Capital”, The Concise Encyclopedia of Economics. Library of Economics and Liberty. Retrieved April 18, 2017, from http://www.econlib.org/library/Enc/ HumanCapital.html

Cohen, D., \& Soto, M. (2007). Growth and Human Capital: Good Data, Good Results. Journal of Economic Growth, 12(1), 5176. doi:10.1007/s10887-007-9011-5

Inkinen, H. (2015). Review of empirical research on intellectual capital and firm performance. Journal of Intellectual Capital, 16(3), 518-565. doi:10.1108/JIC-01-2015-0002

Inkinen, H., Kianto, A., Vanhala, M., \& Ritala, P. (2017). Structure of intellectual capital - an international comparison. Accounting, Auditing \& Accountability Journal, 30(5), 1160 1183. doi:10.1108/AAAJ-11-2015-2291

Jelčić, K. (2007). Intellectual Capital: Handbook of IC Management in Companies. Zagreb: Intellectual Capital Center Croatia.

Krstić, B. (2014). Upravljanje intelektualnim kapitalom preduzeća. Niš: Ekonomski fakultet Univerziteta u Nišu.

Krstić, B., \& Stanišić, T. (2013). The Influence of Knowledge Economy Development on Competitiveness of Southeastern Europe Countries. Industrija, 141(2), 151-168. doi:10. 5937/industrija41-4000

Krstić, B., \& Vukadinović, D. (2009). Valorizovanje resursa znanja - metodologija nacionalnog indeksa intelektualnog kapitala. In Z. Arandjelović, Regionalni razvoj i demografski tokovi zemalja jugoistočne Evrope (pp. 459-468). Niš: Univerzitet u Nišu, Ekonomski fakultet.
Laroche, M., Mérette, M., \& Ruggeri, G. C. (1999). On the Concept and Dimensions of Human Capital in a KnowledgeBased Economy Context. Canadian Public Policy - Analyse de Politiques, 25(1), 87-100.

Lonska, J., \& Mietule, I. (2015). The impact of human capital development on the economic and social development of a country: empirical study. Proceedings of the 10th International Scientific and Practical Conference "Environment. Technology. Resources”. Volume II (pp. 174-180). Rezekne, Latvia: Rezekne Higher Education Institution. doi:10. 17770/etr2015vol2.268

Mankiw, G. N., Romer, D., \& Weil, D. N. (1992). A Contribution to the Empirics of Economic Growth. The Quarterly Journal of Economics, 407-437.

Marimuthu, M., Arokiasamy, L., \& Ismail, M. (2009). Human Capital Development and Its Impact on Firm Performance: Evidence form Developmental Economics. The Journal of International Social Research, 2(8), 265-272.

Nerdrum, L., \& Erikson, T. (2001). Intellectual Capital: A Human Capital Perspective. Journal of Intellectual Capital, 2(2), 127-135. doi:10.1108/14691930110385919

Neycheva, M. (2010). Does Public Expenditure on Education Matter for Growth in Europe? A Comparison Between Old EU Member States and Post-Communist Economies. Post-Communist Economies, 22(2), 141-164. doi:10.1080/ 14631371003740597

Pelinescu, E. (2015). The Impact of Human Capital on Economic Growth. Procedia Economics and Finance, 22, 184-190. doi:10.1016/S2212-5671(15)00258-0

Sullivan, P. H. (1998). Basic Definitions and Concepts. In P. H. Sullivan, Profiting from Intellectual Capital: Extracting Value from Innovation (pp. 19-34). New York: John Wiley \& Sons, Inc.

Sullivan, P. H. (2000). Value-Driven Intellectual Capital - How to Convert Intangible Corporate Assets into Market Value. New York: John Wiley.

Suri, T., Boozer, M. A., Ranis, G., \& Stewart, F. (2011). Paths to Success: The Relationship Between Human Development and Economic Growth. World Development, 39(4), 506522. doi:10.1016/j.worlddev.2010.08.020

Sverdlova, Y. (2014). Influence of Human Capital Development on Competitiveness of the EU Economy. Economic Annals XXI, 7-8(2), 12-15.

Sweetland, S. R. (1996). Human Capital Theory: Foundations of a Field of Inquiry. Review of Educational Research, 66(3), 341359. Retrieved from http://www.jstor.org/stable/1170527

UNDP. (2016). Human Development Report 2016: Human Development for Everyone. New York: UNDP.

WEF. (2016). The Global Competitiveness Report 2016-2017. (K. Schwab, Ed.) Geneva: WEF.

Wilson, R. A., \& Briscoe, G. (2004). The Impact of Human Capital on Economic Growth: A Review. In P. Descy, \& M. Tessaring (Eds.), Impact of Education and Training (Third report on vocational training research in Europe: background report) (pp. 9-70). Cedefop Reference series, 54. Luxembourg: Office for Official Publications of the European Communities.

http://hdr.undp.org/en/data

http://reports.weforum.org/global-competitiveness-index-2017-2018/downloads/ 